\title{
Surviving Indian Town Names in West Jersey
}

\section{VIVIAN ZINKIN}

ShOUld OnE SCAN THE roster of names of communities in New Jersey today, he would find among them such designations as Absecon, Allamuchy, Alloways, Almonesson, Atsion, Cinnaminson, and at least a score of others which are also mentioned in the early documents pertaining to the Province of West Jersey. ${ }^{1}$ Certainly such names are enduring, for they have been in use, if only erratically, for over three hundred years. What is not clear, however, is how many of them originally defined Indian communities and what forces, if any, persuaded them to survive or to be revived to denote similar non-Indian referents. This discussion seeks to find out if there is any pattern of survival among names such as these and, if so, what factors may have influenced their continued use.

It is common knowledge that the Indians originally inhabiting New Jersey were the Lenni-Lenape, who constituted a part of the large Algonquian linguistic family occupying the northeastern part of North America. Of the eight thousand Algonquins living in this area in the mid-seventeenth century, it is estimated that the Lenni-Lenape of New Jersey numbered between two and three thousand. ${ }^{2}$ Just how many of these occupied the territory once known as West Jersey is not exactly known. At any rate, early records for this area offer about 40 names which are believed to have identified Indian communities within the former West Jersey province.

Among the sources for these names is the work of De Laet, a Dutch explorer, whose journal, published in 1625 , comments on the various Indian tribes of this region. ${ }^{3}$ Supporting his statement is that of De

\footnotetext{
1 New Jersey Department of Transportation, Office of Information Services, Local Names, Municipalities and Counties in New Jersey (Trenton, N.J.: The Department, 1974).

2 John E. Pomfret, Colonial New Jersey: A History (New York: Charles Scribner's Sons, 1973), p. 11.

3 Collections of the New-York Historical Society, 2nd ser., I (New York: New-York Historical Society, 1841), p. 315, hereafter cited as NYHS, Coll. (The spellings of De Laet have, in many
} 
Vries, a Dutch traveler who left a record of his voyages made less than a decade later. ${ }^{4}$ A number of maps, dating from the 1630's through 1700, confirm the names found in the early journals. In 1641 a Master Robert Evelin, who had "severall years resided" "just midway between New England and Virginia," wrote a letter describing the location along the eastern shores of the Delaware River of the Indian kings, as he called them, and citing the number of their followers. ${ }^{5}$ Another rich source of names is the Geographia by Peter Lindeström, a Swedish engineer, which records his experiences in New Sweden and which also includes the richly detailed map of the Delaware River which he drew. ${ }^{6}$ To complement these are accounts by several Dutch writers and Englishmen and the various deeds and surveys on record in the New Jersey Archives and the State Library in Trenton, New Jersey.

It is important to understand at the outset that the available material is fragmentary at best and that the specification of the referent of a particular name is comparatively rare in the records themselves. That these designations did indeed mark communities is in large part a conclusion drawn by later historians who laboriously gathered bits of evidence to make such a determination. It must also be pointed out that the term community is used here as one that designates a group of "People with common interests living in a particular area."7 Therefore, names that may have denoted villages, towns, or plantations are all included in this discussion.

For practical purposes it has seemed advisable to divide the names into four categories: (1) those employing or related to a tribal name; (2) nontribal names, many of which were nonce forms; (3) designations of Indian towns and villages, so specified in the records; and (4) Indian plantation names.

Many of the names of Indian communities that employed the tribal name were obsolete before the end of the seventeenth century. Armewamex, for example, was noted in 1625 by De Laet. ${ }^{8}$ It subsequently

\footnotetext{
instances, been altered to conform with those more frequently employed during the seventeenth century.)

4 NYHS Coll., 2nd ser., III, pt. I, pp. 1-136.

5 Robert Evelin, "Letter," in Beauchamp Plantaganet, A Description of the Province of New Albion (Washington: P. Force, 1837), pp. 21-23, hereafter cited as Evelin, "Letter."

6 Peter Lindeström, Geographia Americae, trans. Amandus Johnson (Philadelphia: The Swedish Colonial Society, 1925); hereafter references to the text cited as Lindeström; to the map or editorial comment regarding the map, as Lindeström, Map.

7 Webster's New Collegiate Dictionary (Springfield, Mass.: G. \& C. Merriam Co., 1973).

8 NYHS, Coll., I, p. 303.
} 
appears, variously spelled, as Eriwoneck ${ }^{9}$ Ermomex ${ }^{10}$ Arwames ${ }^{11}$ Arwaymouse, which Gabriel Thomas, an English traveler here in 1698, writes "is the Name of an Indian Town,"12 and in at least ten other orthographic forms. The town has generally been placed either at Gloucester ${ }^{13}$ or in the area drained by Newton Creek and Big and Little Timber Creeks. ${ }^{14}$ A gloss suggested for this name is "Point of land," 15 a translation which lends support to those who have located this settlement at Gloucester Point. ${ }^{16}$ Another town, Kleyne or Kloijne Siconese, ${ }^{17}$ naming a center of the Siconese Indians, ${ }^{18}$ may have been located near Oldmans Creek in Salem County, ${ }^{19}$ the term Kleyne indicating a comparatively small group of the tribe, for a larger group of the same Indians had established a community on the western side of the Delaware River near present-day Lewes in the state of Delaware. ${ }^{20} \mathrm{At}$ the same time another group had settled, probably at Raccoon Creek in New Jersey, naming their settlement simply Siconese, for the tribe.

Matikongh, ${ }^{21}$ Momakaraongh, ${ }^{22}$ Moetoankaronck, ${ }^{23}$ and Yacomanshaghkings, ${ }^{24}$ also tribal names, denote four other seventeenth century Indian communities, all of these, like most of the early epithets, now

\footnotetext{
9 Evelin, "Letter," p. 22.

10 Adriaen Van Derdonck, Map of New Netherlands, reproduced in Alfred M. Heston, Absegami: Annals of Eyren Haven and Atlantic City, 1609-1904, I (Camden, N.J.: Sinnickson Chew \& Sons Co., 1904).

11 Lindeström, Map.

12 Gabriel Thomas, An Historical and Geographical Account of the Province and Country of Pennsilvania, and of West-New Jersey in America (London: A. Baldwin, 1698; lith. New York: Austin Brody, 1848), p. 9.

13 Gloucester County Courthouse, Gloucester, N.J., Minute Book, Quarter Sessions, Common Pleas, No. 1, 1686-1713, p. 1.

14 A.R. Dunlap and C.A. Weslager, "Toponomy of the Delaware Valley as Revealed by an Early Seventeenth-Century Dutch Map," The Archeological Society of New Jersey, Nos. 15-16 (November, 1958), p. 10.

15 C. A. Weslager, The English on the Delaware, 1610-1682, (New Brunswick, N. J.: Rutgers University Press, 1967), p. 283.

16 John W. Barber and Henry Howe, Historical Collections of the State of New Jersey (New York: S. Tuttle, 1844), p. 220.

17 Dunlap and Weslager, p. 10.

18 NYHS, Coll., I, p. 315.

19 Dunlap and Weslager, p. 10.

20 Ibid.

21 NYHS, Coll., I, p. 315.

22 C. A. Weslager, The Delaware Indians: A History (New Brunswick, N. J.:Rutgers University Press, 1972), p. 36. Professor Weslager cites as his source here what he calls the "New Netherland Map."

23 NYHS, Coll., I, p. 315.

24 Augustin Hermann, Virginia and Maryland, by Aug. Hermann and Thomas Withinbook, 1673.
} 
obsolete. It has been suggested that Momakaraongh was located along Pennsauken Creek; Matikongh in the environs of present Trenton; ${ }^{25}$ Moetoankaronck, inland, at or near the head of Maurice River;26 and Yacomanshaghkings either at Hammonton ${ }^{27}$ or between Glassboro and Vineland ${ }^{28}$ The literature consulted offers no interpretation for these terms except that they signify these particular subtribes.

Glosses are available, however, for two Indian village names, also obsolete today. One of these, Sewapois ${ }^{29}$ which took the name of its tribe, has been given the signification "little river." 30 This settlement has been variously located on the Maurice River, ${ }^{31}$ at Raccoon Creek, ${ }^{32}$ and at Cohansey Creek. ${ }^{33}$ For Sanhican, ${ }^{34}$ a former community at the Falls of the Delaware River, at or near present Trenton, ${ }^{35}$ the meanings given are numerous. They range from a view that the term is a FrenchDutch hybrid, a blend of French sans prefixed to Dutch hikken, literally "without hiccoughs," supposedly recording the impression of the early Dutch, French, or Walloon sailors that these Indians were originally temperate;"36 to "gunlock;"37 to "the flint rocks at the end of the tide." 38

Naraticonck, ${ }^{39}$ which may have been shortened to Raccoon or may be related to the Indian word for raccoon, that is nachenum, ${ }^{40}$ marked an Indian tribal community located on present Raccoon Creek. ${ }^{41} \mathrm{~A}$ local historian notes that Naraticon did indeed name the raccoon once abounding in this region. ${ }^{42}$ Other glosses offer as its meaning "up-

25 Weslager, Delaware Indians, p. 36.

26 Gabriel Thomas Map, signed Philip Lea, London, 1698, in Horace G. Richards, A Book of Maps of Cape May, 1610-1878 (Cape May, N.J.: Cape May Geographic Society, 1954).

27 Heston, Absegami, p. 48.

28 Frank H. Stewart, Indians of Southern New Jersey (n.p.: By the author, 1932), p. 37.

29 NYHS, Coll., I, p. 315.

30 Dunlap and Weslager, p. 11.

31 Isaac Mickle, Reminiscences of Old Gloucester (1845, rpt.) (Woodbury, NJ.: Gloucester County Historical Society, 1968), p. 1.

32 Geo. R. Prowell, The History of Camden County, New Jersey (Philadelphia: L. J. Richards \& Co., 1886), p. 7.

33 Weslager, Delaware Indians, p. 36.

34 NYHS, Coll., I, p. 303.

35 Thomas Campanius Holm, A Short Description of the Province of New Sweden, trans, P.S.

De Ponceau (n.p.: 1702, rpt. n. p. 1833), p. 82.

36 New Jersey Historical Society, Proceedings, "New Series," X, 246, hereafter cited as NJHS, Proceedings.

37 Daniel G. Brinton, The Lenape and Their Legends (Philadelphia: D.G. Brinton, 1885), p. 43.

38 Lindeström, pp. 380-381.

39 NYHS, Coll., I, p. 315.

40 Brinton, p. 42.

41 Stewart, Indians . . . New Jersey, p. 37.

42 Mickle, p. 121. 
stream where they live," and "upstream where the tide flow ends." 43

Three additional tribal names given to communities are found in Master Evelin's letter, ${ }^{44}$ all of these, apparently nonce forms, and all now obsolete. They are Assomoches, possibly on Big Timber Creek; Calcefar, whose location is not clearly defined; and Kechemeches, which was supposedly located either on the Maurice River ${ }^{45}$ or near Cape May. ${ }^{46}$

What may well be a variant of the name Assomoches, noted by Evelin, is Asamo Hacking( $h)$, found on the Lindeström map. The editor of this map points out that the term apparently designates an "Indian village and plantation," located ten to 15 miles from the mouth of Alloways Creek. ${ }^{47}$ A 1702 account of New Jersey calls Asamohockingz an alternate name for Oitsessing or Elfsborg, present Elsinboro, in Salem County. ${ }^{48}$ Lindeström's Geographia gives two glosses for the name: "at the field of the Asomoche-Indians" or "at the land of hogs. " 49 It has also been translated as "land on a bay, inlet, or enclosed water." 50

All surviving tribal names for communities are glossed. Atsion, or Atsayonck, ${ }^{51}$ refers to a tribe whose village may have been located at present East Burlington ${ }^{52}$ or at the town now bearing the name Atsion, further to the east. ${ }^{53}$ It has been variously interpreted as "at the place of shells from the clams,",54 "Indians nearby," 55 and "place of rocks." Another continuing name, Mantas, ${ }^{57}$ bearing the designation of the Mantas Indians, an important New Jersey tribe once occupying the area from Trenton to the southerly part of the state, ${ }^{58}$ marked at least one

43 Dunlap and Weslager, p. 101.

44 Evelin, "Letter," p. 22.

45 C.A. Weslager, "Robert Evelyn's Indian Tribes and Place-Names of New Albion," The Archeological Society of New Jersey, No. 9, 13-14. Weslager defines these as Indian towns and suggests their possible locations.

46 Mickle, p. 1.

47 Lindeström, Map.

48 Holm, p. 46.

49 Lindeström, p. 308.

50 NJHS, Proceedings, "Series 3," V, 121.

51 NYHS, Coll., I, p. 315.

52 Lindeström, Map.

53 Heston, Absegami, p. 49.

54 Lindeström, p. 309.

55 Federal Writers Project, New Jersey, The Origin of New Jersey Place Names (Trenton, N. J.:

New Jersey Public Library Commission, 1945), p. 7.

56 Weslager, "Robert Evelyn's . . Tribes," 10.

57 NYHS, Coll., I, p. 315.

58 Dunlap and Weslager, p. 9. 
center for this group. De Vries, in 1633, also speaks of these Indians as coming from Red Hook, also in the confines of present New Jersey. ${ }^{59}$ The term has generally been translated as "frogs," 60 but Brinton, a compiler of a nineteenth century Indian dictionary, insists that Mante is a misspelling of monthu, a form of Minsi or Monsey, the name of another group of Indians. ${ }^{61}$ Today Mantas survives as Mantua, a town in Gloucester County.

Two seventeenth century journals mention a place called Minisinck(s). In 1685 Thomas Budd writes that "From the Falls of Delaware River the Indians go in Cannows up the said River to an Indian Town called Minisincks, which is accounted from the Falls about eight miles; . . . ."62 And Captain Arent Schuyler, hardly a decade later, recounts that "About Eleaven a Clock I arrived att the Mennissinck " 63 O'Callaghan, a nineteenth century historian who contributed much to the study of New Netherlands, points out that the Delaware tribe called the Mennisinks were located above the forks of the Delaware. ${ }^{64}$ Among the significations given to this term are "place of many islands," 65 "where the Minsi Indians are," 66 "little island," 67 "where the stones are gathered together," 68 and "the water is gone." 69 But as early as 1656 Van der Donck, a Dutch explorer, in his reports represented Minnessink very much like the Dutch minne-zing, meaning "love chant." It has therefore since been argued that this epithet may well have been given by the Dutch explorers to these Indians who later adopted it. ${ }^{70}$

Rancocas, a name still current, once named a subtribe living in a village located on a creek of that name. Indeed, Robert Evelin located Ramcock, the sachem of the tribe, and his followers at the very

59 NYHS, Coll., III, pt. I, p. 26.

60 Samuel Smith, The History of the Colony of Nova-Caesaria, or New-Jersey (Burlington, N.J., 1765 , rpt. Trention: Wm. S. Sharp, 1890), p. 136, note C.

61 Brinton, p. 45.

62 Thomas Budd, Good Order Established in Pennsylvania and New-Jersey . . . in the Year 1685 (New York: William Gowans, 1865), p. 30.

63 Documents Relating to the Colonial, Revolutionary and Post-Revolutionary History of the State of New Jersey, "First Series," II (Newark, N. J., 1880- ), p. 103, hereafter cited as NJA.

64 E. B. O'Callaghan, History of New Netherland, I (New York: D. Appleton and Co., 1846, rpt. Spartanburg, South Carolina: The Reprint Co., 1966), p. 49.

65 NJHS, Proceedings, "New Series," X, 255.

66 Lindeström, p. 354.

67 Donald W. Becker, Indian Place-Names in New Jersey (Cedar Grove, N. J.: PhillipsCampbell Publishing Co., 1964), p. 41.

68 Ibid.

69 Budd, p. 84.

70 NJHS, Proceedings, “New Series,” XI, 155. 
site where the town of Rancocas stands today. ${ }^{71}$ This designation has been glossed as "many kinsmen" 72 and "sloping land," 73 and the stream of that name as "the creek where there are many kinsmen." " One surviving tribal name which may have designated a. Delaware Indian community is Rechaweijgt, ${ }^{75}$ today pronounced and spelled Rockaway. Its original location is obscure, although it has been placed on or at the confluence of Rockaway Creek and the Passaic River ${ }^{76}$ Its present pronunciation may represent an example of folk etymology. No gloss has been found for the name as it is here presented, although a number have been suggested for Rockaway and its etymology.

Also noted on the Lindeström map are several designations for communities that do not necessarily refer to a tribal name. Among these is Sepahacking, believed to have marked an Indian village or plantation once situated in the area of Cohansey Creek and glossed as "land on a river." A7 Another such name is Pessconinghackingh, probably also for an Indian village or plantation, possibly near the site of present Fieldsboro in Burlington County. It is glossed as "at the place of the ball" or "where ball is played."

The Lindeström map notes three other names that may have designated Indian communities: Necawick, in Burlington County, supposedly meaning "deserted" or "lonely house," Menacamickon, on the north bank of Crosswicks Creek, interpreted as "the quill fence or enclosure," "from the fact that a village was located there, palisaded with sharp sticks,"80 and Kagkikanizackien, near present Woodstown in Salem County. The Geographia notes that the creek of this name had the probable meaning of "the creek at the place of the one with the crooked mouth" or of "old-mans creek," an alternate name for the stream, which has survived ${ }^{81}$ Weslager, who has made a considerable study of the Delaware Indians, believes, however, that the name is

71 Weslager, Robert Evelin's . . Tribes, pp. 9, 14

72 Lloyd E. Griscom, The Historic County of Burlington (Mount Holly, N. J.: The Burlington County Cultural and Heritage Commission, 1973), p. 40.

73 Dunlap and Weslager, pp. 8-9.

74 Lindeström, p. 379.

75 Johannes Vingboons, New Sweden, from the Manuscript-Atlas of Johannes Vingboons, ca.

1665, in Monumenta Cartographica, Plate 79.

76 Weslager, Delaware Indians, p. 38.

77 NJHS, Proceedings, "Series 3," V, 121.

78 Lindeström, p. 371.

79 Ibid., p. 359.

80 lbid., p. 349.

81 lbid., p. 327. 
related to the Sikonese Indians and means "at the land or place" of the Sikonesses. ${ }^{82}$ An Indian village named in a 1649 Indian deed $^{83}$ and whose name also occurs on the Lindeström map is Roophakesky, possibly located above Burlington Island. ${ }^{84}$ All these names were hardly in use at the end of the seventeenth century.

In a few instances the records have precisely stipulated that certain names were indicators of Indian communities. Perhaps the earliest of these is Watcessit, noted as "Watcessit town" in a 1634 lease to a Sir Thomas Danby. ${ }^{85}$ A variant of this name, Watcessi, has been glossed as "the place of the crooked stream" and has been placed at Salem ${ }^{86}$ or on the site of Fort Elfsborg, ${ }^{87}$ present Elsinboro. Later seventeenth century deeds record "the Indian town of Alumhatta," 88 "the Indian Town of Itcha-la-men-sey," 89 and "the Indian town of Quoexin," apparently in Burlington County. Another, in 1703, defines property as running "unto an Indian towne called Toquemenching . . . along the Indian Road," leading to a particular plantation. ${ }^{91}$ These five names are now obsolete.

Early documents offer several additional names as markers of Indian settlements. The precise location of one of these, Oneanickon, or Honehonickon, also defined as an Indian town, ${ }^{92}$ probably somewhere in Springfield Township, Burlington County, is unknown. ${ }^{93}$ It may have taken its name from the Indian King, Ockanickon, who died in Burlington in 1681.94 The name has been glossed as meaning "an iron hook or pot hook." 95 Deeds also refer to "the Indian town of Pemisoakin" (now Pennsauken) as located between "two branches of Cimsis-

82 Weslager, Robert Evelin's . . . Tribes, p. 12.

83 B. Fernow, ed., Documents Relating to the Colonial History of the State of New York, XII (Albany: The Argus Company, 1877), p. 49.

84 Lindeström, Map.

85 Samuel Hazard, Annals of Pennsylvania (Philadelphia: Hazard and Mitchell, 1850), pp. 3738.

86 NJHS, Proceedings, "New Series," XI, 156.

87 Weslager, Robert Evelin's . . . Tribes, p. 7.

88 NJA, XXI, p. 354.

89 Ibid., pp. 531-532.

90 Ibid., p. 374.

91 Recorded Deeds, Liber AAA (Trenton, N. J.: New Jersey State Library), pp. 434-435.

92 NJA, XXI, p. 355.

93 Henry H. Bisbee, Sign Posts: Place Names in History of Burlington County, New Jersey (Willingboro, New Jersey: Alexia Press, 1971), pp. 175-176.

94 Amelia M. Gummere, "The Early Quakers in New Jersey," in Rufus M. Jones et al., The Quakers in the American Colonies (New York: Russell \& Russell, 1962), p. 403.

95 Becker, p. 52. 
sinck" (now Cinnaminson) Creek. ${ }^{96}$ Like many other Indian names, this one has been variously interpreted, one gloss being "where the Road winds down the hill," which alludes to "the high banks on the South side" of the creek of that name. ${ }^{97}$ A more popular interpretation results from the folklore issuing from William Penn's acquisition of land along Pennsauken Creek. One writer suggests that the name commemorates the fact that Penn "reserved a hawking privilege in the sale of lands there, and thence called the stream Pennshawking creek." 98 Another glosses the name as "Penn's cultivated land," or "Penn's farm," 99 and still another as Penn's "water inlet or outlet."100 Pennsauken survives as the name of a New Jersey town.

Land records also refer to but do not name "the Indian Town" situated near the main branch of Alloways Creek. ${ }^{101}$ The deeds list one other name, Wishalimensy, which historians regard as denoting an Indian town. ${ }^{102}$ It is believed to have been located on the present site of Rocktown in Hunterdon County. ${ }^{103}$

Several names for Indian plantations have been registered, two of these on the Lindeström map. Arothama Plantage, located at or near Cooperstown in Burlington County, and Mechopinachan, at present Florence, in the same county, are so designated by the editor of the map. The latter name has been glossed as "the place of the large potato." 104 Both of these designations are no longer current.

Other Indian plantation names are found in deed and survey books. Asinkoweerkong, an alternate for Sheroppees Plantation, was located above Trenton, on a branch of the Raritan River. ${ }^{105}$ Nancuttings Old Plantation ${ }^{106}$ and Osononds Plantation, ${ }^{107}$ both seemingly in Burlington County, marked places whose ownership was ascribed to particular Indian individuals. Finally, Ye Indians Plantations, situated some-

\footnotetext{
96 NJA, XXI, p. 353.

97 Historical Society of Pennsylvania, Manuscript Collection, John Lippincott Papers, "John Roberts, the emigrant, 1776."

98 John Clement, Sketches of the First Emigrant Settlers in Newton Township, Old Gloucester County, West New Jersey (Camden, N. J.: Sinnickson Chew, 1877), pp. 233-234.

99 NJHS, Proceedings, "New Series," XI, 155.

100 Federal Writers Project, N. J., The Origin . . Names, p. 25.

101 NJA, XXI, p. 385.

102 Ibid., p. 388.

103 NJHS, Proceedings, "New Series," XI, 516.

104 Lindeström, p. 347.

105 Recorded Deeds, Liber AAA, pp. 434-435.

106 NJA, XXI, p. 381.

107 Frank H. Stewart, Historical Data, rpt. from 1932-33 Year Book, New Jersey Society of Pennsylvania (Woodbury, N. J.: Gloucester County Historical Society, n. d.), p. 7.
} 
where in Burlington County, ${ }^{108}$ is also mentioned. All of these plantation names are also no longer current.

One of the purposes of this discussion is to determine how many of these designations for Indian communities still serve as names of towns. Of the roughly 40 items in this corpus, only six continue to denote communities today. Five of the survivors, Atsion, Mantua, Minisink, Rancocas, and Rockaway, represent original tribal names, all of them, except Minisink, located on waterways of the same name. The sixth, Pennshauken, a nontribal designation, also names the stream along which it sits.

It is true that several of the names that are now obsolete also were located on streams carrying the village name. In all instances, however, before the end of the seventeenth century, the Indian name had already yielded to a European substitute. For example, Asamo Hackingskijl was then generally called Salem Creek or Salem River; Kagkikanizackiens Sippus had turned into Oldmans Creek; and Peskozackassingskijl had become Woodbury Creek. ${ }^{109}$ Interestingly enough, the records do show an effort on the part of the colonists to change the name of Rancocas Creek to that of Northampton River. In the deed books one finds mention of acreage on "Rankokus alias Northampton River" as early as $1682^{110}$ while court records continue to refer to the Northampton River as late as $1701 .^{111}$ Although the English epithet persisted for several decades as an alternate to the Indian name, it eventually gave way to the earlier designation, perhaps because Rancocas had been in use not only by the Indians but also by the Dutch and Swedes who had been in the region before the British had established themselves there.

It appears then that the names that have survived are in four instances those that bear the same name as the waterway on or near which they were and still are located. Atsion was also situated on a stream, now called the Atsion River, but the name for the waterway itself does not appear in the seventeenth century records that have been consulted. It is located somewhat inland, away from the mainstream of activity, which circumstance may account for the later naming of the stream and the persistence of the original village name. Both Minisink

108 Council of Proprietors of the Western Division of New Jersey, Surveys: Book A, 1686-1745, Liber I (Microfilmed by the Rutgers University Library, 1953), p. 37.

109 NJA, XXI, pp. 541, 545, 355, respectively.

110 Ibid., p. 349.

111 Aaron Leaming and Jacob Spicer, The Grants, Concessions and Original Constitutions of the Province of New Jersey, 2nd ed. (Philadelphia: W. Bradford, 1881), p. 578. 
and Rockaway are situated in a part of the state that is still sparsely settled and still remote from those pursuits that dominate the essential life of the state. On the other hand, Mantua, Pennsauken, and Rancocas name communities situated in a part of New Jersey dominating its political life even when this area had a provincial status-and for some time thereafter.

In conclusion, it seems that those names which have continued as town names are those that originally marked communities which were located on waterways that bore the village designation and where settlement and activity were both bustling and extensive or where such conditions were hardly realized. One must remark also, considering the persistence of the name Rancocas, that only those names have survived that have shown strength enough in usage to resist even strong competition.

\section{Glassboro State College.}

\section{JOHN LYMAN}

Dr. John Lyman, professor emeritus of environmental chemistry (chemical oceanography) at the University of North Carolina, and a long-standing member of the American Name Society, died at his home in Chapel Hill on November 17, 1977, at the age of 62 .

He was active as a researcher in maritime history, had one of the world's largest collections of nautical documents and artifacts, and had written extensively in maritime journals (he was an occasional contributor to Names). A native of Berkeley, California, he earned his B.S. degree from the University of California in 1936, and his M.S. and Ph.d. from Scripps Institution of Oceanography in 1958; during World War II, he served as an officer in the Navy, retiring from the Naval Reserve in 1975 at the rank of Captain.

During his 40-year career, Dr. Lyman was director of the division of oceanography, Navy Hydrographic Office; program director for oceanography, National Science Foundation, and oceanography coordinator, Bureau of Commercial Fisheries. He was also U.S. coordinator of the International Indian Ocean Expedition in 1961-64, a trustee of the National Maritime Historical Association, and newsletter editor for the North Carolina Society of Mayflower Descendants. Of him, President William C. Friday of the University of North Carolina said, "John Lyman was one of America's distinguished scientists [and] most instrumental in establishing the highly important marine sciences program in the University and on our coast. We are indeed grateful for his exceptional service. . . ." Public Health Dean Bernard G. Greenberg remarked, "Dr. Lyman's death was a shock, for he was still a young man when he retired from the University four years ago to pursue his main interest-the sea and maritime history. His extraordinarily broad and international experience in marine sciences and administration of federal programs in oceanography were valuable assets to our academic and research programs in the School of Public Health." 